\title{
SOLID-LIQUID EXTRACTION OF BIOACTIVE COMPOUNDS FROM YERBA MATE (ILEX PARAGUARIENSIS) LEAVES
}

\author{
Isabel B. B. Gerke ${ }^{*}$, Fabiane Hamerski ${ }^{1}$, Agnes P. Scheer ${ }^{1}$, Vitor R. Silva ${ }^{1}$ \\ ${ }^{1}$ Federal University of Paraná - UFPR - PR, isabelbubans@yahoo.com.br
}

\begin{abstract}
The aqueous batch extraction of bioactive compounds from yerba mate leaves was evaluated at different temperature $\left(20,50,80^{\circ} \mathrm{C}\right)$ and stirring $(0,200,400 \mathrm{rpm})$ conditions. The chlorogenic acid (5-CQA) and caffeine (Ca) concentration over time was evaluated by two mathematical models (equilibrium-dependent and intra-particle diffusion). The kinetics data show that the extraction process approached the equilibrium about 120-180 min. The equilibrium-dependent model presented the worse quality of model adjustment. The model derived from Fick's second law was found to be more suitable to describing the kinetics indicating that is the diffusion intra-particle stage that controls the extraction rates. The diffusion coefficients varied from $1.07 \times 10^{-4}$ to $7.91 \times 10^{-4} \mathrm{~mm}^{2} \mathrm{~min}^{-1}$ to 5-CQA and from $1.18 \times 10^{-4}$ to $8.22 \times 10^{-4} \mathrm{~mm}^{2} \mathrm{~min}^{-1}$ to $\mathrm{Ca}$, where higher values are obtained at higher temperatures.
\end{abstract}

Keywords: yerba mate; aqueous extract; chlorogenic acid; caffeine, diffusion coefficient.

\section{Introduction}

Yerba mate is a main product obtained from the Ilex paraguariensis, Aquifoliaceae family tree, which is generally consumed as mate (hot drink), "tereré" (iced drink) and "chá matte" (roasted leaves infusion) [1]. This plant grows in Brazil, Argentina, Uruguay and Paraguay and represents an important native product, witch belong to the culture for centuries, but in the last years has gained public attention in EUA and Europe [2].

The interest in yerba mate-based products is due to their stimulating and energizing characteristics as the health-promoting effects including antioxidant, antimicrobial, antiinflammation, anticancer, antidiabetic, antiobesity and diuretic activity [2-5]. Those benefits are attributed to secondary metabolites present in yerba mate leaves such as caffeine and chlorogenic acid, considered bioactives [6-10].

Besides the popular beverages, yerba mate extracts have been used to development new food products such as beers, creams, candy and teas [11-13]. However, to use yerba mate extracts as an ingredient in those products it is necessary to apply a solid-liquid extraction stage that guarantees a bioactive compounds efficient removal from leaves.

Characteristics of solvent, solute and solid matrix and factors such as stirring, time and temperature influence the yield and quality of the extract $[14,15]$. So, it is necessary to determine adequate process conditions by kinetic study to apply mathematical modeling for optimization, simulation and control of solid-liquid extraction increasing industry profit by better use of time, energy and solvent [16].

Several mathematical models are used to describe the mechanisms involved on extraction kinetics of bioactive compounds from plants. Equilibrium-dependent and intraparticle diffusion are extensively reported in the literature [17-20]. So, the aim of this work was to evaluate the kinetic in yerba mate individual bioactive compounds (chlorogenic acid and caffeine) extraction. Also, the fitting data to two models was investigated to determine the best process parameters and the phenomena involved. 


\section{Experimental}

\subsection{Materials}

Yerba mate was obtained from Vier Ltda. (Palmeirinha, Paraná State, Brazil). The leaves had geometric characteristics of flat plate with thickness of $0.23 \pm 0.04 \mathrm{~mm}$ measured by a digital micrometer (Mitutoyo, model PK0505). Deionized water was used as solvent for the extraction process. The chemicals 5-caffeoylquinic acid (5-CQA), caffeine (Ca), theobromine (Th) and rutin $(\mathrm{Ru})$ were purchased from Sigma-Aldrich Chemical Co. (St. Louis, MO, USA). Methanol (chromatography grade) was purchased from Vetec Ltda. (São Paulo, São Paulo State, Brazil). All other chemicals used were of analytical grade.

\subsection{Solid-liquid extraction experiments}

Batch extraction was adapted from Jensen and Zanoelo (2012) and carried out in $1000 \mathrm{~g}$ of deionized water with $7 \%(\mathrm{~m} / \mathrm{m})$ solid-liquid ratio. The extraction process was controlled by a thermostatic batch (Quimis, model Q215S) and a mechanical stirring (Quimis, model Q25M). The kinetics were conducted in different temperature $\left(20,50\right.$ and $\left.80^{\circ} \mathrm{C}\right)$ and stirring $(0,200$ and $400 \mathrm{rpm}$ ) conditions, according to central composite design (CCD) with four $\left(2^{2}\right)$ factorial points and center point. The kinetic study of bioactive compounds extractions were taken out in different times $(3,10,20,30,60,120$ and $180 \mathrm{~min})$. The samples of yerba mate extracts $(5.0 \mathrm{~mL})$ were filtered and stored in amber vials under refrigeration $\left(4^{\circ} \mathrm{C}\right)$ until the moment of analysis.

The bioactive compounds extraction rate $n\left(\mathrm{mg} \mathrm{L}^{-1} \mathrm{~min}^{-1}\right)$ was calculated using the Eq. 1 .

$$
n=\frac{C\left(t_{i}\right)-C\left(t_{i-1}\right)}{t_{i}-t_{i-1}}
$$

Where $C\left(t_{i}\right)$ and $C\left(t_{i-1}\right)$ are the solute concentration in liquid phase $\left(\mathrm{mg} \mathrm{L}^{-1}\right)$ at specific time $t_{i}$ $(\mathrm{min})$ and at time $\mathrm{t}_{\mathrm{i}-1}(\mathrm{~min})$ prior to $\mathrm{t}_{\mathrm{i}}$, respectively.

\subsection{Chlorogenic acid and caffeine quantification}

The bioactive compounds concentrations in yerba mate aqueous extract were determined by high-pressure liquid chromatography (HPLC) according with Gerke et al. [21], adapted from Dutra et al. [22]. The evaluated compounds were: chlorogenic acid (5-caffeoylquinic acid, 5CQA) and caffeine (Ca).

\subsection{Modeling Equations}

The yerba mate bioactive compounds extraction kinetics was evaluated using two mathematical models. As know, solid-liquid extraction is a multistep process which involves mechanisms such as solute convection and diffusion. Then, equilibrium-dependent model and intra-particle diffusion model, from Fick's law have been applied to describe the kinetics curves obtained experimentally.

\subsubsection{Equilibrium-dependent model}

This model is based on the solute mass transfer between solid and liquid phases, driven by the solute concentration gradient at time and the equilibrium solute concentration. The internal diffusion is neglected [19]. A mass balance for the solute describes these 
considerations (Eq. 2). The left-hand side term of this equation is the rate of solute accumulation and the right-hand is the net rate of solute transfer from the solid to the liquid phase [23].

$$
\frac{d C}{d t}=k\left(C_{\infty}-C\right)
$$

Where $C$ is the solute concentration in liquid phase $\left(\mathrm{mg} \mathrm{L}^{-1}\right)$ at time $t(\mathrm{~min}), k$ is the solute transport coefficient $\left(\mathrm{min}^{-1}\right)$ and $C_{\infty}$ is the solute concentration equilibrium $\left(\mathrm{mg} \mathrm{L}^{-1}\right)$.

Integrating the first-order differential Eq. and considering the boundary condition $(\mathrm{t}=0, \mathrm{C}=0)$, the equilibrium-dependent model is obtained (Eq. 3).

$$
C(t)=C_{\infty} \cdot\left(1-e^{-k \cdot t}\right)
$$

\subsubsection{Intra-particle diffusion model}

Another procedure to mathematically describe the solute extraction is a model derived from Fick's second law (Eq. 4), where is assumed: flat plate solid geometry approaches and the internal diffusion governs the solute transport from the solid to the liquid phase.

$$
\frac{\partial X}{\partial t}=D \frac{\partial^{2} X}{\partial x^{2}}
$$

Assuming the following initial and boundary conditions:

Initial conditions: $\quad \mathrm{X}=\mathrm{X}_{0} ; \quad \mathrm{t}=0 ;-\mathrm{L} \leq \mathrm{x} \leq \mathrm{L}$

Boundary conditions: $\mathrm{X}=0 ; \mathrm{t}>0$; at $\mathrm{x}= \pm \mathrm{L}$; and $\partial \mathrm{X} / \partial \mathrm{x}=0 ; \mathrm{t} \geq 0$; at $\mathrm{x}=0$

Where $X$ is the solute concentration in the solid particle $\left(\mathrm{mg} \mathrm{g}^{-1}\right), D$ is the diffusion coefficient for the solute in the solvent $\left(\mathrm{mm}^{2} \mathrm{~min}^{-1}\right), L$ is the half of the solid particle thickness $(\mathrm{mm})$, and $x$ is the distance in the direction of the transfer $(\mathrm{mm})$.

The diffusion model of solid-liquid extraction proposed by Crank [24] to a flat plate geometry can be expressed as the solute transferred mass from the particle sample at any time, $M$, relative to the total amount transferred after infinite time, $M_{\infty}$ (Eq. 5).

$$
\frac{M}{M_{\infty}}=1-\frac{8}{\pi^{2}} \sum_{n=1}^{\infty} \frac{1}{(2 n+1)^{2}} \cdot \exp \left\{-\frac{(2 n+1)^{2} \pi^{2} D t}{4 L^{2}}\right\}
$$

Eq. 5 was rewrite using the solute concentration in the solid during the extraction time (Eq. 6). A mass balance to the solid particle (Eq. 7) was utilized to transform the experimental data (bioactive compounds concentration in liquid phase, $\mathrm{mg} \mathrm{L}^{-1}$ ) in terms of solute concentration in solid, considering that initial concentration at liquid phase is zero.

$X=X_{0}+\left(X_{\infty}-X_{0}\right) \cdot\left[1-\frac{8}{\pi^{2}} \sum_{n=1}^{\infty} \frac{1}{(2 n+1)^{2}} \cdot \exp \left\{-\frac{(2 n+1)^{2} \pi^{2} D t}{4 L^{2}}\right\}\right]$

$X=X_{0}-C \cdot \frac{v}{m}$

Where $X_{\infty}$ is the solute concentration in the solid particle at equilibrium $\left(\mathrm{mg} \mathrm{g}^{-1}\right) ; X_{0}$ is the initial solute concentration in the solid particle $\left(\mathrm{mg} \mathrm{g}^{-1}\right)$, determined by successive extractions according with Dutra et al. (2010) and measurement by HPLC, section 2.4, $v$ is the total water extraction volume (L) and $m$ is the yerba mate mass used at the batch extraction $(\mathrm{g})$.

\subsection{Statistical analysis}

The analysis of variance (ANOVA) was applied to validate the models. The mass transfer models were adjusted by non-linear least-squares regression analysis at 95\% confidence interval. The Levenberg-Marquardt algorithm was employed as the interactive 
method, and StatSoft STATISTICA software (version 10.0) was used for all of the calculations. The sum of squared residuals (SSR), the average absolute relative deviation (AARD) and coefficient of determination $\left(\mathrm{R}^{2}\right)$ were determined as the evaluation criteria for the models.

\section{Results and discussion}

\subsection{Bioactive compounds extraction kinetics}

The bioactive compounds extraction kinetic curves obtained showed a typically extraction curve behavior in all experimental conditions and analyzed responses, data not shown. Initially with a fast increase of concentrations then a slow stage of extraction observed through the extraction rate decay over time (Figure 1).

Extraction process can be easily separated in two defined steps: a fast extraction (washing stage), where the "available compounds" at the particle surface are leaching in the bulk liquid phase and a slow extraction (diffusion stage), that is the diffusion intra-particle solute stage and represents the step that controls the extraction rates in most cases $[18,20,25]$.
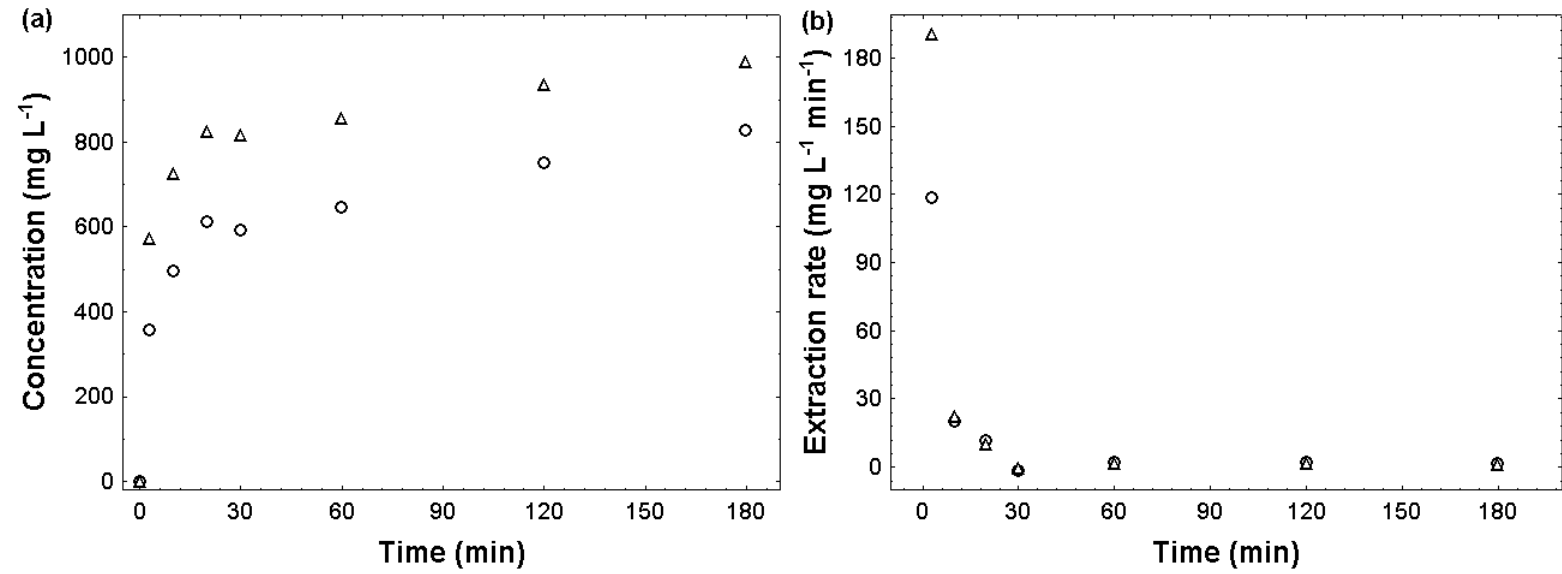

Figure 1: Aqueous extraction kinetics (a) and extraction rate (b) of chlorogenic acid and caffeine $(\Delta)$ from yerba mate leaves at $80{ }^{\circ} \mathrm{C}$ and $400 \mathrm{rpm}$.

Chlorogenic acid content ranged from $554.07 \pm 1.66$ to $826.38 \pm 60.07 \mathrm{mg} \mathrm{L}^{-1}$ and caffeine content ranged from $742.78 \pm 26.59$ to $987.36 \pm 49.19 \mathrm{mg} \mathrm{L}^{-1}$ in the extracts at $180 \mathrm{~min}$. The highest and lowest solute content were obtained in the extraction condition of $80{ }^{\circ} \mathrm{C} / 400$ $\mathrm{rpm}$ and $20{ }^{\circ} \mathrm{C} / 0 \mathrm{rpm}$, respectively. The bioactive compounds aqueous extraction tends to equilibrium in the evaluated time interval, where all compounds concentrations had no significant difference $(\mathrm{p}<0.05)$ between the last two times they were measured and the extraction rate was less than $2 \mathrm{mg} \mathrm{L}^{-1} \mathrm{~min}^{-1}$. The same behavior was observed for both bioactive compounds measured in all extraction conditions analyzed.

\subsection{Mathematical modeling of bioactive compounds extraction}

The modeling data obtained from the bioactive compounds extraction from yerba mate are presented below. For both experimental responses (5-CQA and Ca concentrations) and extraction conditions the models applied were validated by ANOVA and presented random residuals.

The different models parameters for chlorogenic acid and caffeine extraction are summarized in Table 1 and 2, repectively. All models had high $\mathrm{R}^{2}$ values which ranged from 
0.89 to 0.99 to 5-CQA and from 0.92 to 0.99 to $\mathrm{Ca}$, indicating that the chosen models can describe these bioactive compounds extraction process. The equilibrium-dependent model fit presented higher SSR and AARD values, indicating the worse quality of model adjustment. This result maybe related with the assumption of internal diffusion within the solid neglected in a process which this phenomenon represents the step that controls the yield in most cases.

Intra-particle diffusion model (Figure 2) presented the best goodness fit to 5-CQA and Ca kinetics. This shows that the extraction rate is controlled by internal diffusion of solutes in the solid phase. The yerba mate leaves haven't a particle size too small, like a fine powder, and because of this there is a diffusional resistance to transport of the solute within the solid and, therefore, the diffusion step should control the process [26].

Table 1. Modeling parameters of chlorogenic acid extraction from yerba mate leaves ${ }^{\mathrm{a}}$.

\begin{tabular}{|c|c|c|c|c|c|c|}
\hline Model & Parameter & $20^{\circ} \mathrm{C} 0 \mathrm{rpm}$ & $80^{\circ} \mathrm{C} 0 \mathrm{rpm}$ & $20^{\circ} \mathrm{C} 400 \mathrm{rpm}$ & $80^{\circ} \mathrm{C} 400 \mathrm{rpm}$ & $50^{\circ} \mathrm{C} 200 \mathrm{rpm}$ \\
\hline \multirow{4}{*}{$\begin{array}{c}\text { Equilibrium- } \\
\text { dependent }\end{array}$} & $\mathrm{k} \times 10^{2}$ & $2.86 \pm 0.23^{\mathrm{b}}$ & $6.95 \pm 1.55^{\mathrm{a}}$ & $4.90 \pm 0.87^{\mathrm{ab}}$ & $7.55 \pm 1.88^{\mathrm{a}}$ & $6.98 \pm 1.14^{\mathrm{a}}$ \\
\hline & $\mathrm{R}^{2}$ & 0.990 & 0.920 & 0.942 & 0.891 & 0.961 \\
\hline & $\operatorname{SSR} \times 10^{3}$ & 5.37 & 68.48 & 28.29 & 97.34 & 26.25 \\
\hline & AARD & 11.99 & 16.05 & 17.24 & 18.86 & 13.97 \\
\hline \multirow{4}{*}{$\begin{array}{c}\text { Intra- } \\
\text { particle } \\
\text { diffusion }\end{array}$} & D $\times 10^{4}$ & $1.07 \pm 0.10^{\mathrm{c}}$ & $5.49 \pm 1.07^{b}$ & $1.85 \pm 0.25^{\mathrm{c}}$ & $7.91 \pm 1.39^{\mathrm{a}}$ & $2.71 \pm 0.33^{\mathrm{c}}$ \\
\hline & $\mathrm{R}^{2}$ & 0.990 & 0.973 & 0.976 & 0.984 & 0.983 \\
\hline & SSR $\times 10^{3}$ & 5.18 & 13.92 & 11.76 & 9.59 & 11.19 \\
\hline & AARD & 10.02 & 9.33 & 10.63 & 5.73 & 7.79 \\
\hline
\end{tabular}

Means with same letters in the same line represent not statistically differences according to the Tukey's test $(\mathrm{p}<0.05)$.

${ }^{\text {a }}$ Extraction condition: $7 \%(\mathrm{~m} / \mathrm{m})$ solid-liquid ratio.

Table 2. Modeling parameters of caffeine extraction from yerba mate leaves ${ }^{\mathrm{a}}$.

\begin{tabular}{|c|c|c|c|c|c|c|}
\hline Model & Parameter & $20^{\circ} \mathrm{C} 0 \mathrm{rpm}$ & $80^{\circ} \mathrm{C} 0 \mathrm{rpm}$ & $20^{\circ} \mathrm{C} 400 \mathrm{rpm}$ & $80^{\circ} \mathrm{C} 400 \mathrm{rpm}$ & $50^{\circ} \mathrm{C} 200 \mathrm{rpm}$ \\
\hline \multirow{4}{*}{$\begin{array}{c}\text { Equilibrium- } \\
\text { dependent }\end{array}$} & $\mathrm{k} \times 10^{2}$ & $3.13 \pm 0.31^{\mathrm{b}}$ & $22.99 \pm 4.70^{\mathrm{a}}$ & $5.60 \pm 1.06^{\mathrm{b}}$ & $18.62 \pm 5.16^{a}$ & $8.60 \pm 1.83^{b}$ \\
\hline & $\mathrm{R}^{2}$ & 0.984 & 0.969 & 0.936 & 0.924 & 0.935 \\
\hline & SSR $\times 10^{3}$ & 15.18 & 39.74 & 57.58 & 102.09 & 70.24 \\
\hline & AARD & 14.94 & 8.83 & 17.24 & 14.25 & 15.30 \\
\hline \multirow{4}{*}{$\begin{array}{c}\text { Intra- } \\
\text { particle } \\
\text { diffusion }\end{array}$} & $\mathrm{D} \times 10^{4}$ & $1.18 \pm 0.09^{\mathrm{b}}$ & $8.22 \pm 1.66^{\mathrm{a}}$ & $2.16 \pm 0.32^{b}$ & $6.19 \pm 1.58^{a}$ & $3.24 \pm 0.55^{\mathrm{b}}$ \\
\hline & $\mathrm{R}^{2}$ & 0.993 & 0.975 & 0.972 & 0.943 & 0.966 \\
\hline & SSR $\times 10^{3}$ & 6.72 & 32.14 & 25.41 & 77.21 & 36.78 \\
\hline & AARD & 3.36 & 7.13 & 10.35 & 11.11 & 10.62 \\
\hline
\end{tabular}

Means with same letters in the same line represent not statistically differences according to the Tukey's test $(\mathrm{p}<0.05)$.

${ }^{\text {a }}$ Extraction condition: $7 \%(\mathrm{~m} / \mathrm{m})$ solid-liquid ratio.

Fick's law has been commonly employed to determine diffusion coefficients in the bioactive compounds extraction [27,28]. The diffusion coefficient values can be changed by independent variables as temperature $[29,30]$. The coefficient values varied from $1.07 \times 10^{-4}$ to $7.91 \times 10^{-4} \mathrm{~mm}^{2} \mathrm{~min}^{-1}$ to 5 -CQA and from $1.18 \times 10^{-4}$ to $8.22 \times 10^{-4} \mathrm{~mm}^{2} \mathrm{~min}^{-1}$ to $\mathrm{Ca}$. These values did not demonstrate significant relation with stirring which can be observed in tables 1 and 2, where the values presented small variation at same temperature conditions. Since the solid phase gives the controlling resistance, as mentioned above, the effect of stirring is not pronounced [26]. On the other hand, temperature showed to play an important role in the diffusion phenomena, where the higher diffusion coefficients are obtained at higher temperatures. Acording to Cacace and Mazza [31], the increase in diffusivity due the temperature may be caused by an increase of the internal energy of the molecules and thus their mobility, and a reduction of the viscosity. 
The most significant resistance barrier for the diffusion process is the cell wall and membranes of plant materials [32]. The experimental data deviation to model at $80^{\circ} \mathrm{C}$ after 20-30 min extraction may be related with the possible cell wall disruption by heat exposure. Therefore, the bioactive compounds can more easily move to the bulk and the intra-particle diffusion no longer controls the extraction rate.

Since the diffusion coefficient values of all evaluated compounds could not found in previous works except caffeine, we can only compare this calculated values with Ziaedini et al. [15] work which studied the caffeine extraction from green tea (Camelia sinensis) leaves. Their values of caffeine diffusion coefficient in water varied from $5.04 \times 10^{-4}$ to $13.98 \times 10^{-4}$ $\mathrm{mm}^{2} \mathrm{~min}^{-1}$ to a temperature range of $50-90^{\circ} \mathrm{C}$, indicating that the prediction model used in our study gives accurate and realistic results.


Figure 2. Comparison of experimental data with intra-particle diffusion model results for chlorogenic acid (a) and caffeine (b) extraction kinetics from yerba mate leaves. Symbols: experiments; lines:

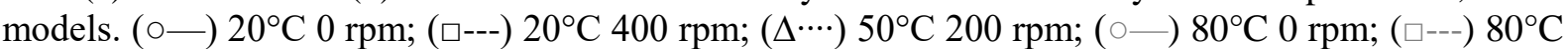
$400 \mathrm{rpm}$.

\section{Conclusions}

The data obtained in the present study showed that yerba mate leaves are a very rich natural source of bioactive compounds and their extraction can be performed in a simple aqueous batch process which makes it possible to use in food products. The use of higher temperatures increases the extraction rate and the stirring had little influence on the yield of the process. The kinetics study and the use of mathematical models were provided a better understanding of the extraction process, which is governed by the intra-particle diffusion step.

\section{Acknowledgements}

The authors are grateful for the scholarship provided by CAPES, the research grant and support of the Graduation Program of Food Engineering (Federal University of Paraná, Curitiba, Brazil) and the yerba mate supplied by Vier Ltda.

\section{References}

1. Colpo AC, Rosa H, Lima ME, Pazzini CEF, Camargo VB, Bassante FEM, et al. Yerba mate (Ilex paraguariensis St . Hill.)-based beverages: How successive extraction influences the extract composition and its capacity to chelate iron and scavenge free radicals. Food Chem. 2016;209:185-195. 
2. Heck CI, De Mejia EG. Yerba mate tea (Ilex paraguariensis): A comprehensive review on chemistry, health implications, and technological considerations. J. Food Sci. 2007;72(9):138-151.

3. Filip R, López P, Giberti G, Coussio J, Ferraro G. Phenolic compounds in seven South American Ilex species. Fitoterapia. 2001;72:774-778.

4. Burris KP, Harte FM, Davidson PM, Stewart CNJ, Zivanovic S. Composition and Bioactive Properties of Yerba Mate (llex paraguariensis A. St.-Hil.): A Review. Chil. J. Agric. Res. 2012;72(2):268-275.

5. Orjuela-Palacio JM, Zamora MC, Lanari MC. Consumers' acceptance of a highpolyphenol yerba mate/black currant beverage : Effect of repeated tasting. Food Res. Int. 2014;57:26-33.

6. Bastos DHM, Fornari AC, Queiroz YS, Torres EAFS. Bioactive Compounds Content of Chimarrão Infusions Related to the Moisture of Yerba Maté ( Ilex Paraguariensis ) Leaves. 2006;49(3):399-404.

7. Pagliosa CM, Vieira MA, Podestá R, Maraschin M, Zeni ALB, Amante ER, et al. Methylxanthines, phenolic composition, and antioxidant activity of bark from residues from mate tree harvesting (Ilex paraguariensis A. St. Hil.). Food Chem. 2010;122(1):173-178.

8. Souza AHP, Corrêa RCG, Barros L, Calhelha RC, Santos-Buelga C, Peralta RM, et al. Phytochemicals and bioactive properties of Ilex paraguariensis: An in-vitro comparative study between the whole plant, leaves and stems. Food Res. Int. 2015;78:286-294.

9. Butiuk AP, Martos MA, Adachi O, Hours RA. Study of the chlorogenic acid content in yerba mate (Ilex paraguariensis St . Hil.): Effect of plant fraction, processing step and harvesting season. J. Appl. Res. Med. Aromat. Plants. 2016;3:27-33.

10. Valerga J, Shorthose R, Lanari MC. Antioxidant activity of yerba mate extracts : Interactions between the individual polyphenols. Eur. J. Lipid Sci. Technol. 2013;115(5):513-525.

11. Vieira MA, Rovaris AA, Maraschin M, Simas KN, Pagliosa CM, Podestá R, et al. Chemical Characterization of Candy Made of Erva-Mate (Ilex paraguariensis A . St . Hil .) Residue. J. Agric. Food Chem. 2008;56:4637-4642.

12. Bracesco N, Sanchez AG, Contreras V, Menini T, Gugliucci A. Recent advances on Ilex paraguariensis research: Minireview. J. Ethnopharmacol. 2011;136(3):378-384.

13. Godoy RCB, Deliza R, Gheno LB, Licodiedoff S, Frizon CNT, Ribani RH, et al. Consumer perceptions, attitudes and acceptance of new and traditional mate tea products. Food Res. Int. 2013;53(2):801-807.

14. Azmir J, Zaidul ISM, Rahman MM, Sharif KM, Mohamed A, Sahena F, et al. Techniques for extraction of bioactive compounds from plant materials: A review. J. Food Eng. 2013;117(4):426-436.

15. Ziaedini A, Jafari A, Zakeri A. Extraction of Antioxidants and Caffeine from Green Tea ( Camelia sinensis ) Leaves: Kinetics and Modeling. Food Sci. Technol. Int. 2010;16(6):505-510.

16. Amendola D, Faveri DM De, Spigno G. Grape marc phenolics : Extraction kinetics, quality and stability of extracts. J. Food Eng. 2010;97(3):384-392.

17. Torun M, Dincer C, Topuz A, Sahin-Nadeem H, Ozdemir F. Aqueous extraction kinetics of soluble solids, phenolics and flavonoids from sage (Salvia fruticosa Miller) leaves. J. Food Sci. Technol. 2014;52:2797-2805.

18. Linares a. R, Hase SL, Vergara ML, Resnik SL. Modeling yerba mate aqueous extraction kinetics: Influence of temperature. J. Food Eng. 2010;97(4):471-477.

19. Pin KY, Chuan AL, Rashih AA, Rasadah MA, Law CL, Choong TSY. Solid-liquid 
extraction of betel leaves (Piper Betle L.). J. Food Process Eng. 2011;34:549-565.

20. Chan C, Yusoff R, Ngoh G. Modeling and kinetics study of conventional and assisted batch solvent extraction. Chem. Eng. Res. Des. 2013;92:1169-1186.

21. Gerke IBB, Hamerski F, Scheer AP, Silva VR. Clarification of crude extract of yerba mate (Ilex paraguariensis ) by membrane processes: Analysis of fouling and loss of bioactive compounds. Food Bioprod. Process. 2017;2:204-212.

22. Dutra FLG, Hoffmann-Ribani R, Ribani M. Determination of phenolic compounds by isocratic high performance liquid chromatografic method during storage of yerba-mate. Quim. Nova. 2010;33(1):119-123.

23. Jensen S, Zanoelo ÉF. Kinetics of aqueous extraction of mate (Ilex paraguariensis) leaves. J. Food Process Eng. 2012;36(2):220-227.

24. Crank J. THE MATHEMATICS OF DIFFUSION. 2nd ed. Clarendon Press Oxford; 1975.

25. Meullemiestre A, Petitcolas E, Maache-rezzoug Z, Chemat F, Rezzoug SA. Impact of ultrasound on solid-liquid extraction of phenolic compounds from maritime pine sawdust waste. Kinetics, optimization and large scale experiments. Ultrason. Sonochem. 2016;28:230-239.

26. Dutta BK. Principles of mass transfer and separation processes. New Delhi: PHI Learnin Private Limited; 2009.

27. Radha Krishnan K, Sivarajan M, Babuskin S, Archana G, Azhagu Saravana Babu P, Sukumar M. Kinetic modeling of spice extraction from S. aromaticum and C. cassia. J. Food Eng. 2013;117(3):326-332.

28. Segovia FJ, Corral-pérez JJ, Almajano MP. Avocado seed: Modeling extraction of bioactive compounds. Ind. Crops Prod. 2016;85:213-220.

29. Hojnik M, Škerget M, Knez Ž. Extraction of lutein from Marigold flower petals Experimental kinetics and modelling. LWT - Food Sci. Technol. 2008;41(10):20082016.

30. Guerrero MS, Torres JS, Nuñez MJ. Extraction of polyphenols from white distilled grape pomace: Optimization and modelling. Bioresour. Technol. 2008;99(5):13111318.

31. Cacace JE, Mazza G. Mass transfer process during extraction of phenolic compounds from milled berries. J. Food Eng. 2003;59:379-389.

32. Zhao S, Baik O-D, Choi YJ, Kim S-M. Pretreatments for the efficient extraction of bioactive compounds from plant-based biomaterials. Crit. Rev. Food Sci. Nutr. 2014;54(10):1283-97. 